Revisión

\title{
Nuevas perspectivas en el tratamiento del cáncer de pulmón no microcítico: farmacogenómica
}

\author{
M. Cobo Dols, S. Gil Calle, E. Villar Chamorro, I. Alés Díaz, A. Montesa Pino, J. Alcaide García, \\ V. Gutiérrez Calderón, F. Carabante Ocón, J. J. Bretón García, M. Benavides Orgaz
}

\section{Resumen}

La estrategia de tratamiento más utilizada en el cáncer de pulmón no microcítico (CPNM) avanzado es la quimioterapia, concretamente la combinación de dos drogas, principalmente cisplatino con gemcitabina, vinorelbina, taxanos, irinotecan. En el pasado se han hecho intentos en vano de revertir la resistencia a la quimioterapia. La supervivencia en este estadio no suele superar los 8-10 meses con el tratamiento convencional. En el presente, intentos para superar estos resultados se focalizan en la farmacogenómica, con el objetivo de individualizar la quimioterapia basado en aspectos de biología molecular, como los polimorfismos, mutaciones genéticas, y sobreexpresión de genes que pueden funcionar como dianas de los fármacos. La evidencia indica que algunos marcadores genéticos pueden ser predictivos de resistencia a la quimioterapia. Uno de los objetivos en investigación translacional es investigar la aplicación clínica de los sistemas de reparación del DNA. Algunos genes como ERCC1, XPD polymorphisms. RRM1, BCRA1, etc, se relacionan con resistencia a cisplatino y otras drogas.

\section{Palabras clave:}

Cáncer de pulmón no microcítico. Quimioterapia. Farmacogenómica.

Oncología, 2006; 29 (2):55-64

Servicio de Oncología Médica

Hospital Regional Universitario Carlos Haya

Málaga 


\section{Summary}

The most commonly used chemotherapy strategy in advanced non-small cell lung cancer (NSCLC) today is the combination of two drugs, mainly cisplatin with another drug (gemcitabine, vinorelbine, taxanes, irinotecan). In the last decade attempts have been made to overcome chemotherapy resistance without benefit in outcome. There is a "plateau" in the results which seems unable to progress beyond the frontier of 8-10 months of median survival. At present, research in cancer survival is focused on translational pharmacogenomics, with the goal of providing individualized CT based on different genetic traits, such a polymorphisms, gen mutation and overexpresion of drug target gene transcripts, and several molecular assays can been used to tailor chemotherapy in the care of lung cancer patients. Accumulated evidence indicates that many genetic markers are related to chemotherapy resistance. One of the most important goals in translational research is to investigate the clinical use of the DNA repair pathways. Several genes such as ERCC1, XPD polymorphisms. RRM1, BCRA1, etc are related to cisplatin and other drugs resistance.

Key words: Non-small cell lung cancer. Chemotherapy. Pharmacogenomics.

\section{Introducción}

El cáncer de pulmón no microcítico (CPNM) avanzado es la causa más frecuente de muerte por enfermedad maligna tanto en hombres como mujeres y representa el $29 \%$ de las muertes por cáncer. Los datos estimados del año 2000 son una incidencia de 1.2 millones, y una mortalidad de 1.1 millones de muertes por cáncer de pulmón ${ }^{1}$. Alrededor del $80 \%$ pertenecen a la variedad histológica de cáncer de pulmón no microcítico (CPNM). El tratamiento quimioterápico ha demostrado un efecto positivo sobre la supervivencia y la calidad de vida en los pacientes con CPNM en estadios avanzados ${ }^{2}$. La estrategia de tratamiento más común es la combinación de dos drogas, principalmente el cisplatino con otro fármaco (gemcitabina, vinorelbina, taxanos o irinotecán). Sin embargo, en los últimos 20 años la supervivencia a cinco años en CPNM en global ha permanecido en menos del 15\%, y menos del $30 \%$ responderán a la quimioterapia. Prácticamente, en la mayoría de los ensayos randomizados que comparan diferentes combinaciones de quimioterapia basada en cisplatino, no hay diferencia significativa en supervivencia entre los esquemas ${ }^{3-7}$. De todos ellos, el estudio más paradigmático es el de Schiller ${ }^{3}$, en el que se comparan cuatro regímenes: cisplatino más gemcitabina, paclitaxel, docetaxel, y carboplatino más paclitaxel, todos ellos con la misma respuesta, mediana de supervivencia y supervivencia a uno y dos años. Del mismo modo, los estudios que comparan dobletes con y sin cisplatino, tampoco encuentran mejoría en supervivencia para ninguna de ellos ${ }^{5-7}$.

Estos resultados pueden ser interpretados como el reflejo del fracaso de la quimioterapia en el tratamiento del CPNM avanzado, que parece haberse estancado en la frontera de 8-10 meses de mediana de supervivencia, como un infranqueable "plateau" que ninguna combinación con o sin cisplatino, incluso incluyendo tripletes, ha logrado superar. En la revisión de Dra. Isla, et $\mathrm{al}^{8}$ se hace una descripción de los ocho principales estudios randomizados y meta-análisis que han dado lugar a las recomendaciones actuales basadas en la evidencia sobre aspectos del tratamiento quimioterápico en enfermedad avanzada, incidiendo también que para mejorar estos resultados tenemos que recurrir al empleo de estrategias nuevas, con fármacos dirigidos a dianas específicas, y todo el abanico de aplicación de la biología molecular para optimizar el tratamiento. En la última década se han hecho intentos de superar esta vicisitud, como el aumentar la intensidad o la duración de la quimioterapia para revertir su resis- 
tencia, pero el beneficio sólo se observa en un número muy limitado de pacientes ${ }^{9}$. Para intentar mejorar estos resultados, se han planteado numerosas estrategias terapéuticas que incluirían el estudio de nuevos quimioterápicos con mecanismos de acción similares a los clásicos, nuevos fármacos antitumorales que actúan frente a dianas específicas, y el empleo de la farmacogenómica, es decir el uso de la biología molecular con el objetivo de individualizar la quimioterapia, todo ello basado en la aplicación de aspectos genéticos como polimorfismos, metilaciones de diversos genes, mutación de genes y sobreexpresión de genes que codifican dianas de diferentes drogas ${ }^{10}$.

\section{Tratamiento basado en dianas moleculares}

Sin embargo, como preámbulo al desarrollo de la quimioterapia customizada, hay que recordar que el concepto de individualizar el tratamiento sistémico no es nuevo, ya que en los años 70 se comenzó a tratar el cáncer de mama con hormonoterapia en aquellas pacientes que sobreexpresaban receptores hormonales, hasta llegar a nuestros días en los que el empleo de las recientes moléculas contra nuevas dianas, se reduce a pacientes que sobreexpresan estas dianas, como ocurre con los anticuerpos monoclonales frente a proteínas de membrana plasmática, y recientemente en cáncer de pulmón, los inhibidores de la tirosín kinasa, en aquellos tumores con mutaciones del receptor del factor de crecimiento epidérmico (EGFR). Los inhibidores de la tirosín kinasa del EGFR son pequeñas moléculas que compiten con el ATP en su unión a la tirosín kinasa del EGFR, con lo cual inhiben su autofosforilación y la posterior activación en cascada de señalizaciones que conducen a la multiplicación celular, bloqueando el proceso de proliferación y metastatización. La presencia de mutaciones en el dominio tirosín kinasa del EGFR se ha identificado como el mayor determinante de respuesta a agentes inhibidores de dicha tirosín kinasa. Varios trabajos han descrito estas mutaciones y su correlación con sensibilidad a inhibidores de EGFR. La mayoría de las mutaciones se localizan en los exones 18, 19 y 21, y consisten en delecciones y en sustitución de aminoácidos. Estos estudios muestran una alta frecuencia de mutaciones en pacientes con histología de adenocarcinoma, mujeres, no fumadores y asiáticos. Aquellos pacientes con mutaciones tratados con un inhibidor de EGFR pueden conseguir una inusual larga supervivencia ${ }^{10-}$ 13 .

La aplicación del conocimiento de la biología de esta enfermedad, abre un nuevo abanico de posibilidades terapéuticas. Los tratamientos biológicos están diseñados para interferir en vías biológicas aberrantes envueltos en la oncogénesis. En cáncer de pulmón, no sólo hay estudios en fases avanzadas con los fármacos descritos, los inhibidores de la tirosín kinasa, sino que hay una amplia clasificación de posibilidades terapéuticas en este sentido, algunos de ellos en estudios preclínicos, y otros han alcanzado ya estudios fase II y fase III. Pero además, algunos aspectos como combinación con quimioterapia, secuencia, definición de dosis óptima, selección de pacientes, objetivos, etc, sigue aún por definir. Estos fármacos se pueden clasificar según el efecto biológico predominante: a) Inhibidores de la traducción de señales. b) Inhibidores del ciclo celular. c) Vías de inmortalidad celular. d) Moduladores de la apoptosis. e) Antiangiogénicos. f) Agentes anti-invasivos. g) Fármacos en mecanismos transversales. Todos estos fármacos serían objeto de una amplia descripción, que no es nuestro objetivo. En la revisión de Dra. Isla, et $\mathrm{al}^{8}$ se exponen una serie de estudios realizados en primera y segunda línea de cáncer de pulmón no microcítico avanzado con esta gama de fármacos, haciendo mención también a algunas subpoblaciones específicas como son la de los pacientes ancianos y las mujeres con adenocarcinoma

\section{Farmacogenómica}

Este es el tema que nos ocupa en esta revisión. Los ensayos de quimioterapia convencional, incluso aquellos que incluyen nuevas drogas o nuevas moléculas contra dianas específicas se caracterizan por la ausencia de información genética, y por tanto de tests genéticos predictivos. El análisis de marcadores pronósticos podría definir la identificación de marcadores predictivos genéticos para identificar subgrupos quimiorresistentes y quimiosensibles frente a determinados agentes. El fundamento de todo ello reside en la integridad de las vías de reparación del daño sobre el DNA ejercido por las drogas antineoplásicas. Si dichos sistemas de reparación funcionan adecuadamente, en el sujeto normal ha- 
brá menos carcinogénesis, pero en el tumor habrá más quimiorresistencia. Hay suficiente evidencia respecto a ciertos marcadores genéticos que están en relación con resistencia a cisplatino. Debido a que el cisplatino se ha considerado la piedra angular del tratamiento del CPNM avanzado, la mayoría de las investigaciones translacionales se han enfocado en investigar la aplicación clínica del conocimiento de las vías de reparación del DNA en tanto puedan influenciar en la quimiosensibilidad a cisplatino.

\section{A) Vías de reparación del DNA}

Existen diversas vías de reparación del DNA (Figura 1$)^{15}$. La vía de reparación por excisión incluyendo el sistema de reparación por excisión de nucleótidos (NER), que es el más específico y el sistema de reparación de bases (BER), juegan un papel muy destacado en la resistencia a la quimioterapia. El sistema HHR (double strand breaks) inducido por agentes citotóxicos, radioterapia y oxidación de radicales, llevado a cabo por recombinación en cadenas terminales de DNA homólogo y no homólogo. Otras vías son la MMR, y el sistema de reparación en un paso (OSR). La proteína reparadora 06metilguanina-Dna tansferasa (MGMT), interviene en OSR a través de la expulsión de un grupo alquilo de el átomo 06 de guanina en el DNA de las células expuestas a agentes alquilantes.

Al igual que la mayoría de los alquiladores del DNA, el cisplatino actúa como entrecruzador de áreas del DNA, concretamente en la bases de guani-

\section{DNA repair systems}

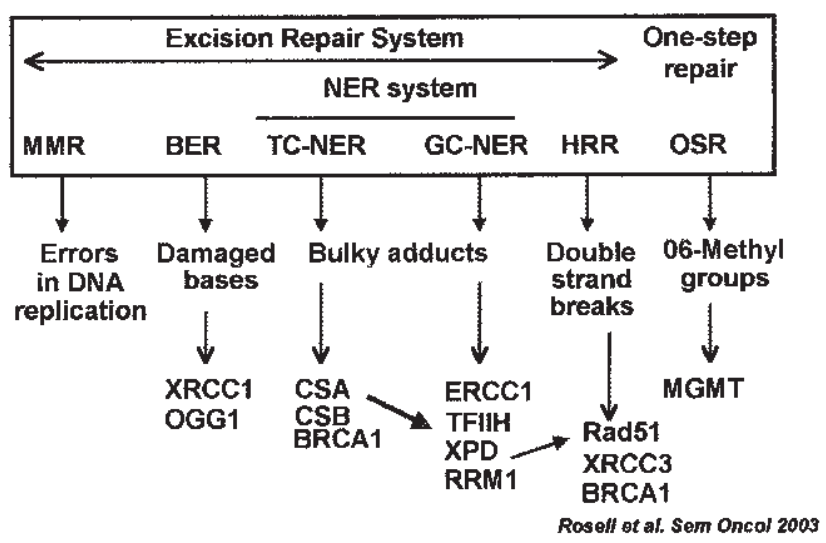

Figura 1. Sistemas de Reparación del DNA. na, produciendo adductos de cisplatino, inhibiendo la replicación del DNA, que es la diana clave en la quimioterapia antineoplásica ${ }^{16}$. En diversos estudios se ha encontrado que hay mejoría tanto en regresión tumoral como en supervivencia en pacientes con niveles elevados de adductos de cisplatino, aunque dichos estudios adolecen de tener un número escaso de pacientes. Por ejemplo, la formación de adductos de cisplatino en leucocitos fue un determinante de respuesta a cisplatino en tumores sólidos ${ }^{17}$, y adductos inducidos por carboplatino fueron encontrados en células bucales de pacientes respondedores a cisplatino o carboplatino ${ }^{18}$. Más recientemente, las modificaciones de las células bucales inducidas por cisplatino fueron determinadas por inmunohistoquímica en pacientes con CPNM tratados con dosis baja de cisplatino diaria y radioterapia concomitante ${ }^{19}$. En otro estudio en que se recogía las células de la mucosa bucal una hora después de la administración del cisplatino y cinco días después, se observó una fuerte asociación entre niveles de adductos y supervivencia; pacientes con niveles altos de adductos de cisplatino tenían un supervivencia de 30 meses, comparado con 5 meses en pacientes con bajos niveles ${ }^{20}$.

El sistema NER es el sistema principal de protección del huésped de desarrollar cáncer de pulmón, y al mismo tiempo, de generar resistencia al cisplatino, ya que es el mecanismo más importante para remover los adductos de cisplatino. El sistema NER se divide en dos subvías: TCR (transcription-coupled repair) and GGR (global genomic repair). La vía GGR actúa en las lesiones de DNA en todo el genoma, tanto en áreas de genes sin transcripción en DNA activo, como en DNA inactivo; la vía TCR sólo repara lesiones en áreas de DNA de genes activos en transcripción ${ }^{21}$. En humanos, NER es el mejor sistema defensivo contra los efectos carcinogénicos de la radiación ultravioleta del sol, y defectos en este sistema de reparación tienen como consecuencia la aparición de enfermedades raras como el xeroderma pigmentosum (XP), que es autonómica recesiva. Pacientes con esta enfermedad presentan hipersensibilidad a la luz del sol, alteraciones pigmentaria y lesiones premalignas en el área de piel expuesta al sol, con una alta incidencia de cáncer de piel. En XP, puede haber 7 grupos de genes deficientes en el sistema NER: XPA a XPG. Se ha detectado pérdida de heteregocidad (LOH) en algunos 
de estos genes XP, la mayoría en cáncer de ovario y menos en colon y en cáncer de pulmón. $\mathrm{La} \mathrm{LOH}$ se relaciona con pérdida de transcripción y la deficiencia de algunos de esos genes puede aumentar la sensibilidad al cisplatino que es comúnmente observada en el cáncer de ovario. El síndrome de Cockayne (CS), es otra enfermedad de fotosensibilización que asocia a defectos en el sistema NER, y consiste en fallo en el crecimiento postnatal, disfunción neurológica progresiva, edad prematura y fotosensibilidad incrementada. Se ha identificado dos grupos complementarios en este defecto: CSA y CSB, ambos con defectos en las funciones que afectan a la subvía TCR ${ }^{22}$.

El primer paso es el reconocimiento del DNA dañado. En TCR, cuando la RNA-polimerasa encuentra la lesión, se ponen en marcha la activación de este sistema a través de las proteínas CSA y CSB. En la subvía GGR, Dos proteínas se han implicado en esta etapa: XPA y el XPC en complejo con HR23B formando un heterodímero. Adicionalmente, la proteína XPE tiene una alta afinidad por el DNA dañado, pero no se conoce su función específica en el reconocimiento del DNA dañado. El complejo XPC-HR23B incrementa la alteración estructural y permite la entrada y acción de el factor TFIIH, que es un complejo con 9 subunidades, dos de ellas son la XPB y XPD, que son helicasas, que abren un segmento de DNA de 30 bases de longitud alrededor de la lesión. Este complejo abierto se estabiliza por la proteína A y XPA. La porción de DNA que contiene la base dañada es escindida por dos endonucleasas, XPG y XPF/ERCC1, XPG rompe la cadena de DNA desde la posición 3’ de la lesión, y el complejo XPF/ERCC1 lo hace desde la posición 5'. Finalmente, se escinde la porción de DNA dañado y el hueco se repara con la DNA- polimerasa, en presencia de factores de replicación. Deficiencias moleculares, tanto en GGR como TCR, en fibroblastos confieren marcada hipersensibilidad a cisplatino comparado con fibroblastos normales. Estos resultados demostraron que cualquier deficiencia en XPA, XPD, XPF, o XPG, confiere marcada hipersensibilidad al cisplatino ${ }^{21}$.

Alrededor de 30 proteínas participan en este proceso de reparación. La eficiencia en remover los adductos de cisplatino por el sistema NER es uno de los determinantes de la resistencia del cisplatino. Bosken ha analizado la relación entre la capacidad de reparación de ADN y la supervivencia en pacientes con CPNM tratados con quimioterapia basada en cisplatino $^{23}$. Es razonable pensar que pacientes con una actividad de reparación del DNA genéticamente determinada óptima, repararían de forma más efectiva el daño en el DNA por la quimioterapia, mientras que sucedería lo contrario en pacientes con una subóptima capacidad de reparación del DNA (DRC). Con esta hipótesis, se evaluó la asociación entre supervivencia y la habilidad de reparar adductos de DNA en pacientes con CPNM tratados con cisplatino. El uso de DRC funcional consistía en la habilidad de reparar adductos inducidos por benzo[a]pireno diol epoxido (BPDE). El DRC fue medido en linfocitos y no en tejido tumoral, por lo que refleja las diferencias en DRC entre pacientes individuales y no por mutaciones somáticas en el tumor. Los resultados mostraron que pacientes que estaban en los cuartiles más altos de DRC tenían un riesgo de muerte de más de dos veces que pacientes en los cuartiles más bajos. La mediana de supervivencia fue de 8.9 meses en pacientes en los cuartiles altos, mientras que 15.8 meses en los cuartiles más bajos, y esta diferencia es estadísticamente significativa $^{23}$. Obviamente, NER es un sistema de multietapas, y el análisis de DRC permite estudiar la integridad del sistema al completo, más que un simple paso. El análisis de la expresión de genes que intervienen en la reparación de ADN puede ayudarnos a individualizar la combinación óptima de agentes quimioterápicos. Los genes ERCC1 (Excision Repair Cross-Complementing 1), XPD (Excision Repair Cross-Complementing 2) RRM (Ribonucleotide Reductase) y BRCA1 (Breast Cancer 1) intervienen de forma crucial en las vías de reparación de ADN.

\section{B) Genes implicados en quimioterapia individualizada}

ERRC1. La sobreexpresión de ERCC1 tiene un importante papel en este proceso ${ }^{24-28}$. Los niveles de ERCC1 mRNA, medidos por PCR cuantitativa fueron examinados en pacientes con cáncer gástrico tratados con cisplatino/Fu, donde el cDNA fue obtenido de tumores gástricos primarios antes de la quimioterapia. La mediana de ERCC1 de los pacientes respondedores fue de 4.6, mientras que el de los pacientes resistentes fue de 8 , con diferencia estadísti- 
camente significativa $^{29}$. El la misma línea, los niveles de ERCC1 mRNA se han correlacionado con resistencia al oxaliplatino en cáncer colorrectal. La mediana de supervivencia para pacientes con expresión de ERCC1 $<4.9$ era de 10 meses, mientras $>4.9$ meses era de 1.9 meses $^{30}$. Estos hallazgos indican que el ERCC1 mRNA intratumoral puede ser un marcador predictivo independiente para combinaciones de oxaliplatino en cancer colorrectal. También se ha analizado el papel de la expresión de ERCC1 en CPNM metastático tratado con gemcitabina-cisplatino. El ERCC1 mRNA fue obtenido de especimenes de biopsia de broncoscopio. La mediana de expresión de ERCC1 >6.7 tenía una mediana de supervivencia de 5 meses, en contra de niveles inferiores en los que la mediana de supervivencia era de 15 meses. Esta diferencia fue estadísticamente significativa, y en el modelo de Cox, ERCC1 es un factor independiente predictivo. El hecho que el punto de corte estuviera relativamente alto indica que se requiere cierto grado de ERCC1 para sinergismo entre cisplatino y gemcitabina ${ }^{31}$. Más recientemente se observó una fuerte correlación entre ERCC1 y niveles mRNA OGG1 en linfocitos periféricos. OGG1 codifica DNA-glicosidasa 8-oxoguanina, que remueve 8-guanina del DNA como parte del BER ${ }^{32}$.

XPD. La ventaja del XPD frente al ERCC1 es la necesidad de suficiente cantidad de material biópsico para una buena determinación del ERCC1, sin embargo XPD puede ser analizado en DNA aislado de linfocitos de sangre periférica. Los polimorfismos XPD han sido correlacionados con bajo DRC analizado en sujetos sanos voluntarios en un estudio epidemiológico de 341 pacientes con cáncer de pulmón y 360 fumadores sanos. Aproximadamente, la mitad de la población estudiada tenía el genotipo Lys751Lys, y también tenían Asp312Asp. Estos pacientes tenían un buen DRC, y presumiblemente serían resistentes a cisplatino. DRC fue más bajo en pacientes con cáncer de pulmón que en sujetos sanos. Las variantes Gln751Gln y Asn312Asn tenían DRC subóptimo ${ }^{33}$. En un estudio piloto en el que se ha examinado los polimorfismos XPD en codones 751 y 312 en el DNA aislado en linfocitos periféricos en 85 pacientes con CPNM localmente avanzados tratados con cisplatino y gemcitabina, se evidencia una correlación significativa en tiempo medio a la progresión de acuerdo con el genotipo XPD ${ }^{34}$.
RRM. La ribonucleótido reductasa es una enzima limitante clave en la síntesis de ADN, ya que es responsable de la redución de ribonucleótidos a sus correspondientes deoxirribonucleótidos, con la provisión correspondiente de precursores para la síntesis de DNA y precursores. Alteración en los niveles de la RRM pueden tener efectos significativos en las propiedades biológicas de las células como son la promoción y progresión tumoral, y el desarrollo de metástasis. Además la subunidad RRM1 interviene en el metabolismo de la gemcitabina y en la reparación de ADN. La sobreexpresión de RRM1 se ha correlacionado con la resistencia a gemcitabina tanto in vitro como en pacientes con CPNM tratados con cisplatino y gemcitabina.

El análisis en la expresión de RRM1 en biopsias de pacientes italianos tratados dentro de un ensayo aleatorizado ${ }^{35}$, reveló diferencias estadísticamente significativas en la supervivencia del grupo de pacientes tratados con gemcitabina y cisplatino. La supervivencia mediana fue de 15.5 meses en aquellos con un nivel bajo de RRM1 y de 6.8 meses en aquellos con un nivel alto $(\mathrm{P}=0.0028)$. El tiempo a la progresión también resultó superior en los pacientes con niveles bajos $(\mathrm{P}=0.05)^{36}$.

Entre 1988 y 2000 el GECP desarrolló un ensayo aleatorizado comparando gemcitabina-cisplatino versus gemcitabina-cisplatino-vinorelbina versus gemcitabina-vinorelbina seguido de vinorelbinaifosfamida ${ }^{4}$. En el grupo asignado a gemcitabinacisplatino, la supervivencia mediana en los pacientes con baja expresión de RRM1 era superior a la de los que tenían alta expresión en el tejido tumoral: 13.7 meses vs 3.6 meses $(\mathrm{P}=0.009)$, así como el tiempo hasta la progresión: 8.4 meses vs 2.7 meses $(\mathrm{P}=0.020)$. En este estudio, hubo una fuerte correlación entre niveles ERCC1 mRNA y RRM1 $(\mathrm{r}=0.4 ; \mathrm{p}<0.001)$. No hubieron diferencias significativas según los niveles de ERCC1, aunque había una tendencia a mayor supervivencia en pacientes con niveles de ERCC1 bajos. La mediana de supervivencia fue más larga en pacientes con niveles bajos de ambos marcadores genéticos ERCC1 Y RRM1, respecto a niveles altos de ambos genes $(\mathrm{p}=0.016)^{37}$.

En un estudio en pacientes con CPNM localmente avanzado tratados con quimioterapia con cisplatino y gemcitabina preoperatorio seguida de cirugía, la expresión mRNA se determinó del material bióp- 
sico de los tumores resecados, y se encontraron correlaciones significativas ERCC1 mRNA y XPD mRNA ( $\mathrm{r}=0.48 ; \mathrm{P}<0.0001)$ y entre RRM1 mRNA y XPD mRNA ( $\mathrm{r}=0.48 ; \mathrm{P}<0.0001)$. También se encontró una correlación cercana a la significación entre ERCC1 mRNA y RRM1 mRNA ( $r=0.22$; $\mathrm{P}=0.07)$. Para niveles de RRM1 mRNA, los pacientes en los cuartiles más bajos tenían un menor riesgo de muerte comparado con aquellos en los cuartiles más altos $(\mathrm{RR}=0.30 ; 95 \% \mathrm{CI}, 0.10-0.91$; $\mathrm{P}=0.033)$. Para niveles XPD mRNA, los pacientes en los cuartiles más bajos (0.08-0.71) tenían un riesgo de muerte más bajo comparado con aquellos en los cuartiles más altos (1.71-3.78) $(\mathrm{RR}=0.40 ; 95 \%$ CI, 0.12-1.37; P=0.145). Para niveles ERCC1 mRNA, los pacientes en los cuartiles más bajos (2.734.96) tenían un riesgo de muerte más bajo comparado con aquellos en los cuartiles más altos (7.4512.31) $(\mathrm{RR}=1.51 ; 95 \% \mathrm{CI}, 0.55-4.10 ; \mathrm{P}=0.422)^{38}$.

BCRA-1. BRCA1 es un gen que juega un papel crucial en varias de las vías de reparación del ADN, y se ha observado niveles disminuidos de BCRA1 mRNA tanto en cáncer de mama esporádico como hereditario ${ }^{39}$, sin embargo su papel en el cáncer de pulmón no ha sido investigado. BCRA1 está implicado en las vías de reparación del DNA, concretamente en la subvía TCR del sistema NER, y la modulación de su expresión se ha relacionado con resistencia a quimioterapia y radioterapia. BCRA1 está también envuelta en la reparación por recombinación homóloga (HHR), al igual que en el MMR (mismatch repair) ${ }^{39,40}$. Estudios preclínicos sugieren que una expresión reducida de BRCA1 incrementa la sensibilidad a agentes que producen un daño en el $\mathrm{ADN}$, por promover la reparación del ADN y la supervivencia celular, con inhibición de la apoptosis. En contraste con este efecto, una expresión elevada de BRCA1 aumenta la sensibilidad de los agentes antimicrotúbulos por inducir la apoptosis en respuesta a dichos agentes ${ }^{41}$. La expresión reducida de BRCA1 en una línea celular de cáncer de mama determinó una gran sensibilidad a cisplatino y etopósido y una gran resistencia a agentes que actúan sobre los microtúbulos, como paclitaxel y vincristina ${ }^{42}$. La reconstitución del gen BRCA1 resultó en un incremento en la resistencia a cisplatino y también en la sensibilidad a agentes antimicrotúbulos ${ }^{43,44}$.

En un grupo de 55 pacientes estadios IIB, IIIA y IIIB que fueron resecados después de recibir qui- mioterapia neoadyuvante con gemcitabina y cisplatino se realizó una cuantificación de la expresión de BRCA1 RNAm en tejido tumoral parafinado, y esta expresión génica se dividió en cuartiles. La supervivencia no se ha alcanzado en los pacientes en el cuartil con menor expresión de BRCA1, fue de 37.8 meses en los pacientes incluidos en los dos cuartiles medios, y fue 12.7 meses en aquellos en el cuartil superior, y esta diferencia es estadísticamente significativa $(\mathrm{P}=0.01)(45)$. Estos hallazgos refuerzan la hipótesis que la expresión de BCRA1 mRNA, podría ser un indicador de resistencia a cisplatino en CPNM, que es consistente con los hallazgos en modelos preclínicos en cáncer de mama.

Actualmente, llevado a cabo por el Grupo Español de cáncer de Pulmón (GECP), ha finalizado el primer ensayo randomizado realizado con el objetivo de contestar a la pregunta si la quimioterapia individualizada basada en aspectos de biología molecular beneficiará a los pacientes con CPNM avanzado (GILT). En este ensayo se aleatoriza a los pacientes a un grupo control en el que se trata con una combinación de cisplatino y taxotere, y un grupo experimental, en el se trata dependiendo de los niveles de ERCC1. Si la sobreexpresión de mRNA ERCC1 es baja, se supone una sensibilidad a cisplatino y el tratamiento es cisplatino más taxotere, y si el nivel de mRNA ERCC1 es alto, los pacientes se tratan con una combinación sin cisplatino, con docetaxel y gemcitabina. En los resultados en 264 pacientes analizados se demuestra un beneficio significativo en respuesta para aquellos pacientes del grupo experimental con niveles bajos de ERCC1, tratados con cisplatino y taxotere. Este es el primer estudio aleatorizado que intenta responder a la pregunta si la quimioterapia individualizada es significativamente mejor que el uso empírico de ésta.

Por otro lado, con el objetivo de evaluar la expresión de RRM1 y de BRCA1 como potenciales marcadores predictivos de quimiorresistencia, el GECP ha comenzado el desarrollo de un estudio clínico piloto en pacientes con resección completa en los que se demuestre invasión ganglionar N1 o N2 en la pieza operatoria. La combinación de quimioterapia adyuvante individualizada se seleccionará según la expresión del mRNA de los genes RRM1 y BRCA1 en el análisis por PCR cuantitativa en tiempo real en el tejido tumoral. Los pacientes con niveles de ex- 
presión de RRM1 y BRCA1 incluidos en el primer cuartil recibirán gemcitabina y cisplatino. Los pacientes con una expresión de RRM1 y BRCA1 incluida en los cuartiles segundo y tercero, recibirán docetaxel y cisplatino. Los pacientes con valores en la expresión de BRCA1 dentro del cuarto cuartil, recibirán docetaxel.

Otros genes. Los genes descritos, no son los únicos estudiados. Hay otros genes pertenecientes al sistema de reparación por excisión de nucleótidos, y otras vías de reparación que se han estudiado en cuanto a expresión y en cuanto a variantes alélicas. Dentro de estos estudios y de otros más, también se está determinando el valor de otros polimorfismos como XRCC-1. En un estudio de pacientes tratados con cisplatino, determinadas variantes alélicas tenían claramente un peor supervivencia. Así, el polimorfismo Arg/Arg se relaciona con mediana de supervivencia de 17,3 meses, el heterocigótico Arg/Gln, de 11,4 meses, y el genotipo Gln/Gln, la mediana de supervivencia fue sólo de 7,7 meses ${ }^{46}$. Por otro lado, en el estudio de Alberola ${ }^{4}$, el valor predictivo del polimorfismo XRCC3 Thr241Met se demuestra en el análisis multivariado, en el que el 20-25\% de pacientes con la variante alélica MetMet, tienen significativamente mejor supervivencia.

\section{C) Metilación de genes}

Las anormalidades genéticas en los protooncogenes y genes supresores están relacionadas con la patogénesis del cáncer de pulmón. Estas alteraciones están relacionadas con cambios en la secuencia del DNA, aunque otro mecanismo que contribuye al desarrollo del cáncer son los cambios epigenéticos. El término de epigenético se refiere al cambio del patrón de expresión genética mediado por alteraciones en la secuencia de nucleótidos de los genes. Las principales modificaciones epigenéticas son la metilación del DNA y modificación de histonas, que ocurren en tumores humanos y pueden dar lugar a silenciación de genes. Las metilaciones sulen ocurrir en citosinas, que están seguidas por una guanina. Cuando se metila un área promotora de un gen, el gen se inactiva y no se transcribe. La hipometilación de genes puede contribuir a la carcinogénesis a través de tres mecanismos: la inestabilidad de cromosomas, reactivación de elementos transposables, o activación de oncogenes. Por otro lado, hipermetilación de islas $\mathrm{CpG}$ puede resultar en la inactivación de genes supresores así como genes reparadores del DNA, resultando en un aumento del daño genético ${ }^{47}$.

La metilación del prototor FANCF está relacionado con sensibilidad al cisplatino en el cáncer de ovario, y la metilación 14-3-3delta le confiere más sensibilidad al cisplatino y a la adriamicina. La metilación del gen CHFR está relacionada en modelos experimentales con aumento de la actividad a drogas antimitóticas ${ }^{48-50}$. La pérdida de la expresión de PTEN es el resultado de la hipermetilación del promotor PTEN en más del 30\% de los glioblastomas, tumores de estómago y de pulmón. La pérdida de la función de PTEN activa la vía PI3K/Akt, que es asociado con resistencia a varios fármacos ${ }^{14}$.

\section{Conclusiones}

Como conclusiones, podemos decir que la quimioterapia individualizada en el cáncer de pulmón se basa en los genes de reparación del daño del DNA, fundamentándose bien en la sobreexpresión de éstos; en polimorfismos, es decir, en la diferencia en supervivencia en pacientes tratados con quimioterapia según determinadas diferencias alélicas; y en la metilación de diversos genes. Hay numerosos estudios con análisis retrospectivos de estos datos, así como en ensayos prospectivos que abalan la relevancia clínica de esta línea de trabajo. En los últimos años ha cambiado el espectro de genes más usados para detectar resistencia a la quimioterapia, siendo cada vez más potentes para este fin.

\author{
Correspondencia: \\ Dr. M. Cobo-Dols, MD \\ Sección de Oncología Médica \\ Pabellón A, $3^{\circ}$ planta Derecha \\ Secretaría de Oncología Médica \\ Hospital Regional Universitario Carlos Haya \\ Avda. Carlos Haya, s/n \\ E-29010 Málaga \\ e-mail: manuelcobodols@yahoo.es \\ e-mail alternativo:mangel.cobo.sspa@juntadeandalucia.es
}




\section{Bibliografía}

1. Parkin DM. Internacional variation. Oncogene 2004; 23 : 6329-6340.

2. Non-small Cell Lung Cancer Collaborative Group. Chemotherapy in non-small cell lung cancer: a meta-analysis using updated data on individual patients from 52 randomised clinical trials. Br Med J 1995; 311: 899-909.

3. Schiller JH, Harrington D, Belani C, et al. Comparison of four chemotherapy regimens for advanced non-small-cell lung cancer. N Engl J Med 2002; 346:92-98.

4. Alberola V, Camps C, Provencio M, et al. Cisplatin plus gemcitabine versus a cisplatin-based triplet versus nonplatinum sequential doublets in advanced non-small-cell lung cancer: a Spanish lung cancer group phase III randomized trial. J Clin Oncol 2003; 21:3207-3213.

5. Smit EF, Van Meerbeeck JPAM, Lianes P, et al. Threearm randomized study of two cisplatin -based regimens and paclitaxel plus gemcitabine in advanced non-small-cell lung cancer: A phase III trial of the European Organization for Research and Treatment of Cancer Lung Cancer Group- EORTC 08975. J Clin Oncol 2003;21:3909-3917.

6. Scagliotti GV, De Marinis F, Rinaldi M, et al. Phase III randomized trial comparing three platinum-based doublets in advanced non-small-cell lung cancer. J Clin Oncol 2002;20:4285-4291.

7. Georgoulias V, Papadakis E, Alexopoulos A, Tsiafaki X, Rapti A, Veslemes M, et al. Platinum-based and non-platinum-based chemotherapy in advanced non-small-cell lung cancer: a randomised multicentre trial. Lancet 2001 May 12;357(9267):1478-84

8. Isla D, Lastra R, Aguirre E, Ortega E, Lambea J, Andrés R. Abordaje terapéutico del carcinoma de pulmón no microcítico avanzado: ¿Estamos "avanzando”?. Oncología 2005; 28 (7): 311 -320.

9. Booton R, Thatcher N. Chemotherapy in advanced non small cell lung cancer: indication, intensity and duration. Curr Opin Oncol. 2002;14(2):191-8.

10. Sarries C, Haura EB, Roig B, et al. Pharmacogenomics strategies for developing customized chemotherapy in nonsmall cell lung cancer. Pharmacogenomics 2002;3:763-780.

11. Lynch TJ, Bell DW, Sordilla R, et al. Activating mutations in the epidermal groth factor receptor underlying responsiveness of non-small-cell lung cancer to gefitinib. N Engl J Med 2004; 350: 2129-2139.

12. Paez JG, Jänne PA, Lee JC, et al. EGFR mutations in lung cancer : correlation with clinical response to gefitinib therapy. Science 2004; 304: 1497-1500.

13. Pao W, Miller V, Zukowski M, et al. EGF receptor gene mutations are common in lung cancer from "never smokers" are associated with sensitivity of tumors to gefitinib and erlotinib. PNAS 2004; 101: 13306-13311.

14. Taron M, Ichinose $\mathrm{Y}$, Rosell R, et al. Activating mutations in the tyrosine kinase domain of the epidermal growth factor receptor are associated with gefitinib response in chemorefractary lung adenocarcinomas. Clin Cancer Res 2005 (in press).
15. Rosell R, Tarón M, Ariza A, et al. Molecular predictors of response to chemotherapy in Lung Cancer. Sem Oncol 2004;31:20-27.

16. Siddik ZH. Mechanisms of action of cancer chemotherapeutic agents: DNA interactive alkylaating agents and antitumour platinum-base drugs. In: aliso MR, ed. The Cancer Handbook. London. England: Nature Publishing Group; 2002:1295-1313.

17. Schellens JHM, Ma J, Planting ASTh, et al. Relationship between the exposure to cisplatin, DNA-adduct formation in leucocytes and tumour response in patients with solid tumours. Br J Cancer 1996;73:1569-1575.

18. Blommaert FA, Charulla M, Terheggen P MAB, et al. Drug-induced DNA modification in buccal cells of cancer patients receiving carboplatin and cisplatin combination chemotherapy, as determined by an immunocytochemical method: interindividual variation and correlation with disease response. Cancer Res 1993;53:5669-5675.

19. Schaake-Koning C, Van den Bogaert W, Dalesio O, et al. Effects of concomitant cisplatin and radiotherapy on inoperable non-small-cell lung cancer. N Engl J Med 1992;326:524-530.

20. Van de Vaart PJM, Belderbos J, De Jong D, et al. DNAadducts levels as a predictor of outcome for NSCLC patients receiving daily cisplatin and radiotherapy. Int J Cancer 2000;89:160-166.

21. Furuta T, Ueda T, Aune G, et al. Transcription-coupled nucleotide excision repair as a determinant of cisplatin sensitivity of human cells. Cancer Res 2002;62:4899-4902.

22. Conforti G, Mazur SJ, Essigmann JM, et al. Inhibition de RNA polymerase II transcription in human cell extracts by cisplatin DNA damage. Biochemistry 1999;38:6204-6212.

23. Bosken CH, Wei Q, Amos CI, et al. An analysis of DNA repair as a determinant of survival in patients with nonsmall cell lung cancer. J Natl Cancer Inst 2002; 94: 10911099.

24. Rosell R, Lord RVN, Taron M, Reguart N. DNA repair and cisplatin resistance in non-small-cell lung cancer. Lung Cancer 2002;38:217-227.

25. Rosell R, Crino L, Danenberg K, et al. Targeted therapy in combination with gemcitabine in non-small-cell lung cancer. Sem Oncol 2003;30:19-25.

26. Sarries C, Haura EB, Roig B, Taron M, Abad A, Scagliotti G, Rosell R. Pharmacogenomic strategies for developing customized chemotherapy in non-small-cell lung cancer. Pharmacogenomics 2003;3:763-780.

27. Rosell R, Taron M, Alberola V, Massuti B, Felip E. Genetic testing for chemotherapy in non-small cell lung cancer. Lung Cancer 2003;41:S97-S102.

28. Rosell R, Taron M, Barnadas A, Scagliotti G, Sarries C, Roig B. Nucleotide excision repair pathways involved in cisplatin resistance in non-small cell lung cancer. Cancer Control 2003;10:297-305.

29. Metzger R, Leichman CG, Danenberg KD, et al. ERCC1 mRNA levels complement thymidilate synthase mRNA levels in predicting response and survival for gastric cancer 
patients receiving combination cisplatin and fluoracil chemotherapy. J Clin Oncol 1998;16:309-16.

30. Shirota Y, Stoehlmacher J, Brabender J, et al. ERCC1 and thymidilate synthase mRNA levels predict survival for colorectal cancer patients receiving combination oxaliplatin and fluorouracil chemotherapy. J Clin Oncol 2001;19:4298-304.

31. Lord RVN, Brabender J, Gandara D, et al. Low ERCC1 expression correlates with prolonged survival after cisplatin plus gemcitabine chemotherapy in non-small cell lung cancer. Clin Cancer Res 2002; 8: 2286-2291.

32. Vogel U, Moller P, Dragsted L, et al. Inter.-individual variation, seasonal variation and close correlation of OGG1 and ERCC1 mRNA levels in full blood from healthy volunteers. Carcinogenesis 2002;23:1505-9

33. Spitz MR, Wu X, Wang Y, et al. Modulation of nucleotide excision repair capacity by XPD polimorfism in lung cancer patients. Cancer Res 2001;61:1354-7.

34. Taron et al. Proc. ASCO, May 2002 -abstract 1322.

35. Scagliotti GV, De Marinis F, Rinaldi M, et al. Phase III randomized trial comparing three platinum-based doublets in advanced non-small cell lung cancer. J Clin Oncol 2002; 20: 4285-4291.

36. Rosell R, Scagliotti G, Danenberg KD, et al. Transcripts in pretreatment biopsias from a three arm randomized trial in metastatic non-small cell lung cancer. Oncogene 2003; 22: 3548-3553.

37. Rosell R, Danenberg KD, Alberola V, et al. Ribonucleotide reductase Messenger RNA expression and survival in gemcitabine/cisplatin-treated advanced non-small cell lung cancer patients. Clin Cancer Res 2004; 10: 13181325.

38. Rosell R, Felip E, Taron M. Gene expression as a predictive marker of outcome in stage IIB-IIIA-IIIB nos-small cell lung cancer after induction gemcitabine-based chemotherapy followed by resectional surgery. Clin Cancer Res;2004;10:4215-4219.

39. Kennedy RD, Quinn JE, Johnston PG and Harkin DP. BR-
CA1: mechanisms of inactivation and implications for management of patients. Lancet 2002;360:1007-1014.

40. Mullan PB, Quinn JE, Gilmore PM, McWilliams S, Andrews $\mathrm{H}$, Gervin C, McCabe N, McKenna S, White P, Song $\mathrm{YH}$, et al. BRCA1 and GADD45 mediated G2/M cell cycle arrest in response to antimicrotubule agents. Oncogene 2001;20:6123-6131.

41. Kennedy RD, Quinn JE, Mullan PB, et al. The role of BRCA1 in the celular response to chemotherapy. J Natl Cancer Inst 2004; 96: 1659-1668.

42. Lafarge S, Sylvain V, Ferrara M, et al. Inhibition of BRCA1 leads to increased chemoresistance to microtubule-interfering agents, an effect that involves the JNK pathway. Oncogene 2001; 20: 6597-6606.

43. Mullan PB, Quinn JE, Gilmore PM, et al. BRCA1 and GADD45 mediated G2/M cell cycle arrest in response to antimicrotubule agents. Oncogene 2001; 20: 6123-6131.

44. Quinn JE, Kennedy RD, Mullan PB, et al. BRCA1 functions as a differential modulator of chemotherapy-induced apoptosis. Cancer Res 2003; 63: 6221-6228.

45. Taron M, Rosell R, Felip E, et al. BRCA1 mRNA expression levels as an indicator of chemoresistance in lung cancer. Hum Mol Genet 2004; 13: 2443-2449.

46. Gurubhagavatula S, Liu G, Park S, et al. XPD and ARCC1 genetic polimorphimss are prognostic factors in advanced non-small cell lung cancer patients treated with platinum chemotherapy. J Clin Oncol 2004;22(13):2594- 2601.

47. Esteller M. Relevance of DNA methylation in the management of cancer. Lancet Oncology 2003;4:351-358

48. Chan TA, Hermeneking H, Langauer C, et al. 14-3-3 is required to prevent mitotic catastrophe after DNA damage. Nature 1999;401:616-20

49. Susuki H, Itoh F, Toyota M, et al. Inactivation of the 14-33 gene is associated with $5{ }^{\circ} \mathrm{CpG}$ island hypermetylation in human cancers. Cancer Res 2000;60:4353-4357.

50. Mizuno K, Osada H, Konishi H, et al. Aberrant hypermetylation of the CHRF prophase checkpoint gene in human lung cancer. Oncogene 2002;21:2328-2333 